УДК $343.161 / .162(477+4.672 € C)$

С. Л. Шаренко, Л. А. Зуб

\title{
КОМПАРАТИВНИЙ АНАЛІЗ НОРМАТИВНОГО РЕГУ ЛЮВАННЯ ДІЯЛЬНОСТІ СЛІДЧОГО СУДДІ В ОКРЕМИХ ЄВРОПЕЙСЬКИХ КРАЇНАХ ТА В УКРАЇНІ
}

У сучасному глобальному світі спостерігається закономірне зближення правових систем окремих держав та, зокрема, їх кримінальних та кримінально-процесуальних інститутів. Кримінальний процесуальний кодекс України в редакції 2012 року вперше в незалежній Україні вводить абсолютно новий процесуальний інститут - слідчого суддю, головним завданням якого є судовий контроль за дотриманням прав, свобод та інтересів осіб у кримінальному провадженні.

Однак історія виникнення судового контролю на стадії досудового розслідування має глибоке коріння. Одним із перших цей процесуальний інститут запровадили в середньовічній Англії, де була введена процедура "Habeas Corpus", відповідно до якої населення отримало право на оскарження вільному і незалежному судді дій органів королівської влади, які застосували до них тримання під вартою. Зазначене було визначено у Вестмінстерському статуті 1275 року.

Право на справедливий і безсторонній суд було проголошено у Великій хартії вольностей (Англія), а згодом у Біллі про права (Америка) та у Декларації прав людини і громадянина (Франція). Так, ст. 39 Великої хартії проголошувала, що жодна вільна людина не може бути заарештована або взята під варту, або позбавлена володіння, або оголошена поза законом, інакше як за законним вироком рівним їй i за законом держави. Поправка 6 Білля про права передбачає право обвинуваченого на публічний розгляд справи безстороннім судом присяжних того штату або округу, в якому вчинено злочин. При цьому обвинувачений мав право на інформування про сутність та підстави обвинувачення, на допомогу адвоката для свого захисту.

Потім інститут судового слідчого як процесуального інституту (екстраординарного) судового контролю та суб'єкта спеціально уповноваженого проводити досудове розслідування був введений у Франції. Слідчий суддя цієї країни виконує як слідчі, так і судові функції. Окрім його слідчих повноважень, які він здійснює особисто або делегує офіцеру кримінальної поліції, він наділяється правом застосування заходів процесуального примусу. КПК Франції також визначає як суб'єктів кримінального провадження суддю зі звільнення та позбавлення волі та суддю, який представляє інтереси потерпілих. Суддя зі звільнення та позбавлення волі (juge des libertes et de la detention), до якого звертається слідчий суддя, наділений монополією виносити накази про тримання під вартою підозрюваного або про подовження строків тримання під вартою. Він поділяє зі слідчим суддею повноваження щодо здійснення судового контролю під час досудового розслідування. За клопотанням прокурора або слідчого судді він надає дозвіл на проведення обшуку у кримінальних справах щодо митних чи податкових злочинів; нічні обшуки щодо злочинів, пов'язаних з організованою злочинністю; дозвіл на тримання під вартою; примусову госпіталізацію. Суддя, який представляє інтереси потерпілих 
(juge delegue aux victims, JUDEVI), на прохання потерпілого сприяє застосуванню заходів, альтернативних судовому переслідуванню прокурора Республіки; компенсації збитків; здійсненню кримінального посередництва; спрямування для надання медичної, соціальної допомоги; реалізації інших належних потерпілому процесуальних прав [ 2 , с. 307-308, 320].

Набагато пізніше судовий контроль був запроваджений у Росії, коли в 1860 році в Наказі судовим слідчим було визначене правило, відповідно до якого за кожним фактом затримання особи вони мусили складати письмову постанову та протягом доби передавати її до суду для перевірки.

У Статуті кримінального судочинства $1864 \mathrm{p}$. для унеможливлення обвинуваченому ухилитися від слідчого застосовувалися такі заходи: 1) відібрання виду на проживання або зобов'язання їх підпискою про явку до слідчого та невиїзд з міста проживання; 2) передача під особистий нагляд поліції; 3) передача на поруки; 4) взяття завдатка; 5) домашній арешт; 6) взяття під варту. Крім цього, передбачалося брати під варту тільки осіб, які вчинили тяжкі та особливо тяжкі злочини. В обранні запобіжного заходу враховувалось не тільки суворість покарання, яке йому загрожує, але і сила представлених проти нього доказів, можливість сховати сліди злочину, стан здоров'я, стать, вік і стан обвинуваченого в суспільстві.

Оперативність судового контролю за Статутом кримінального судочинства 1864 року вражає: скарга на дії слідчого передається суб'єкту контролю - окружному суду протягом 3 днів, а в разі, якщо це скарга на затримання особи - протягом доби. Розглядалася скарга в перший робочий день у судовому засіданні за участю всіх зацікавлених осіб.

Результатом подальшої еволюції концепції захисту прав людини на стадії досудового розслідування є ст. 8 Загальної декларації прав людини, прийнятої Генеральною Асамблеєю ООН у 1948 р., що передбачає право кожної людини на ефективне відновлення компетентними національними судами ії порушених прав, наданих законом. Ч. 1 ст. 6 Конвенції про захист прав і основних свобод (1950) проголошує, що кожна людина у визначенні її громадянських прав та обов’язків або у висуненні проти неї будь-якого кримінального обвинувачення має право на відкритий розгляд упродовж розумного строку незалежним і безстороннім судом, створеним відповідно до закону. Ст. 14 Міжнародного пакту про громадянські і політичні права (1966) гарантує кожному право на публічний розгляд будь-якого кримінального обвинувачення, пред'явленого йому справедливим, компетентним, незалежним і безстороннім судом, створеним на підставі закону [4, с. 82-84].

Інститут судового контролю за здійсненням досудового розслідування притаманний сучасному кримінальному процесу багатьох країн Європи. Так, кримінальний процес Федеративної Республіки Німеччина (далі - ФРН) серед суб’єктів, які діють за своїм волевиявленням, визначає слідчого суддю. КПК ФРН визначає, що слідчий суддя при дільничному суді є компетентним у розслідуванні, яке проводиться прокуратурою при земельних судах, а слідчий суддя Верховного Суду $\Phi Р Н$ - у розслідуванні складних злочинів. До компетенції слідчих суддів віднесено вчинення найважливіших процесуальних дій щодо обвинувачених: видання наказу про арешт та попереднє взяття під варту; попередне затримання; застава; 
арешт майна з метою забезпечення конфіскації грошових сум, виплати грошового штрафу або судових витрат; арешт майна у разі очікуваного призначення покарання майнового характеру; тимчасова заборона займатися певною професійною діяльністю; тимчасове позбавлення прав водія [2, с. 129, 142-157].

В Австрійській Республіці суддя земельного суду одноособово вирішує питання щодо приєднання доказів до справи; призначення і подовження терміну слідчого арешту та інших заходів процесуального примусу; порушень суб'єктивних прав органами прокуратури або поліції; припинення попереднього розслідування; стягнення судових витрат; виплати гонорарів експертам і перекладачам [2, с. 198-210].

Кримінально-процесуальне законодавство Швейцарської Конфедерації передбачає взяття обвинуваченого під варту на підставі письмового наказу слідчого судді або на підставі письмового наказу суду з питань примусових заходів (“die Zwangsmassnahmengerichte”). Суди з питань примусових заходів належать до кантональних судів, їхню постанову може скасувати лише Федеральний кримінальний суд [2, с. 261-268].

Відмінною рисою кримінально-процесуальної системи Італії є чітке розмежування між стадіями досудового розслідування і судового розгляду. Слідчий суддя (Giudice per le indagini preliminary, GIP) призначається для розслідування кожного злочину. Слідчий суддя застосовує всі запобіжні заходи, а також проводить перевірку повноважень прокурора шляхом розгляду клопотань прокурора, які могли б обмежити або порушити права і свободи особи [2, с. 372-375].

Відповідно до ч. 2 ст. 164 КПК Литовської Республіки окремі процесуальні дії в рамках досудового розслідування здійснює суддя досудового розслідування, яким $є$ суддя апілінкового (дільничного) суду, призначений головою цього суду для здійснення таких повноважень: обирати і мотивувати застосування процесуально-примусових заходів; приводити до присяги і допитувати свідків і потерпілих; допитувати підозрюваних; приймати постанови прокурора про припинення досудового розслідування; приймати постанови прокурора про відновлення досудового розслідування; розглядати скарги учасників процесу з приводу дій співробітників досудового розслідування і прокурора; за поданням прокурора здійснювати інші дії [2, с. 477, 496-497].

За кримінально-процесуальним законодавством Латвійської Республіки слідчим суддею є суддя районного (міського) суду, якому голова суду на певний термін доручив контролювати дотримання прав людини у кримінальному процесі. Саме він приймає рішення про застосування, зміну або скасування примусових заходів, проведення окремих процесуальних дій: огляд публічно недоступної території або приміщення і предметів на цій території; огляд транспортного засобу або комп’ютера; примусовий огляд особи; обшук; розкриття даних, збережених в електронній інформаційній системі; зобов'язання журналіста або редактора засобу масової інформації вказати джерело опублікованої інформації [2, с. 531, 543-544].

Судді з кримінального переслідування передбачені КПК Республіки Молдова. Вони дають дозвіл на проведення огляду приміщення або житла (за відсутності згоди власника); освідування підозрюваного, обвинуваченого, свідка або потерпілого; на проведення ексгумації; обшуку; на проведення спеціальної розшукової діяльності; застосовує запобіжні заходи [2, с. 670-671]. 
Важлива роль у кримінальному процесі Королівства Іспанія належить слідчому судді, який відповідає за законність досудового розслідування. Слідчий суддя дотримується принципу офіційного розслідування, оскільки він відповідає за всі рішення на стадії досудового розслідування. Він виконує або наказує поліції здійснювати відповідні слідчі дії з метою отримання і фіксування доказів незалежно від того, свідчать вони на користь обвинувачення чи на користь захисту. Слідчий суддя не зв'язаний діями слідчого, а це означає, що він має право зобов'язати слідчого виконати будь-які слідчі дії, які вважатиме необхідними, за власною ініціативою (ex officio). Слідчий суддя приймає заяви від свідків; вимагає інформацію про підозрюваного; обирає запобіжні заходи; застосовує заходи безпеки; вирішує клопотання сторін про проведення слідчої дії; приймає рішення про завершення досудового розслідування: рішення про закриття кримінальної справи або рішення про передачу справи до відповідного суду [2, с. 702].

За КПК Болгарії суд здійснює судовий контроль під час розслідування і після завершення досудового розслідування. Попередній судовий контроль здійснюється за проведенням слідчої чи процесуальної дії: видачі дозволу на проведення обшуку, виїмки, особистого обшуку, огляду, якщо вони є невідкладними; відібрання зразків для порівняльного дослідження, яке пов'язане з проникненням в організм людини; вилучення поштової або телеграфної кореспонденції; дозволу на використання спеціальних розшукових засобів. Подальший судовий контроль полягає у: схваленні протоколів обшуку, виїмки, особистого обшуку, огляду, якщо вони були невідкладними; оскарження до суду запобіжного заходу у вигляді грошової застави; оскарження до суду примусового заходу у вигляді заборони на виїзд за межі Болгарії. Поточний судовий контроль полягає у здійсненні слідчої дії самим суддею: допит обвинуваченого перед суддею; допит свідка перед суддею. Тільки суд може застосувати запобіжний захід у вигляді тримання під вартою та заходи примусу у вигляді відсторонення від посади; направлення обвинуваченого у психіатричний стаціонар; забезпечення цивільного позову, грошового стягнення, конфіскації і заборони наближатися до потерпілого [2, с.737, 751].

Як видається, міжнародно-правовий досвід регулювання питання судового захисту під час досудового розслідування є значним. Досить лапідарні норми міжнародного права дають змогу дійти однозначного висновку про те, що концентрований вираз забезпечення права на захист суб'єктивних прав, свобод та законних інтересів - це справедливий, незалежний, безсторонній судовий захист, який на досудовому розслідуванні забезпечує слідчий суддя, а під час судового провадження - суд.

Відповідно до п. 18 ч. 1 ст. 3 КПК України слідчий суддя - це суддя суду першої інстанції, до повноважень якого належить здійснення у порядку, передбаченому КПК, судового контролю за дотриманням прав, свобод та інтересів осіб у кримінальному провадженні та в окремих випадках, пов'язаних із наданням дозволів на проведення негласних слідчих (розшукових) дій, - голова чи за його визначенням інший суддя відповідного апеляційного суду.

Статус слідчого судді суду першої інстанції набувається суддею після обрання такої особи зборами суддів зі складу суддів цього суду. 
Про самостійність цього виду судової діяльності свідчить особливий порядок визначення судді районного та апеляційного суду як слідчого судді. У районному суді слідчого суддю обирають збори суддів за пропозицією голови суду, а якщо така пропозиція не підтримана - за пропозицією будь-кого із суддів, які беруть участь у зборах суддів. У чинному Законі України «Про судоустрій і статус суддів» не визначено: чи може суддя, кандидатуру якого запропоновано для обрання слідчим суддею, заявити собі самовідвід; чи можуть збори суддів без згоди самого судді обрати його слідчим суддею. Слідчим суддею апеляційного суду є голова цього суду або за його визначенням інший суддя цього суду. Рішення слідчого судді носять імперативний характер, здебільшого (за винятком ухвал, зазначених у ст. 309 КПК) підлягають негайному і безапеляційному виконанню. Тоді як усі види вироків та ухвал суду підлягають як апеляційному, так і касаційному оскарженню.

Слідчий суддя організаційно і функціонально належить до судового органу i, здійснюючи повноваження з судового контролю, діє від імені суду, що узгоджується з положеннями Конституції України.

Слідчий суддя як новий суб'єкт кримінального судочинства України є носієм судової влади. Він здійснюе діяльність, спрямовану на забезпечення недопущення протиправного й необгрунтованого обмеження конституційних прав і свобод особи на досудових стадіях кримінального провадження шляхом превенції та захист прав і свобод особи, тобто на їх відновлення у разі порушення. Роль слідчого судді багатоаспектна і полягає у забезпеченні режиму законності у кримінальному провадженні, захисту конституційних прав і свобод особи й розширення змагальності на досудовому провадженні.

До повноважень слідчого судді також віднесено забезпечення законності та обгрунтованості обмеження конституційних прав і свобод людини на досудовому провадженні; прийняття рішення про застосування заходів кримінально-процесуального примусу; надання дозволу на проведення слідчих та інших процесуальних дій, що обмежують конституційні права людини; розгляд скарг на дії (бездіяльність) та рішення слідчого та прокурора.

Слід погодитися з думкою ВО. Попелюшко, який пропонує розділити повноваження слідчого судді за такими критеріями: 1) повноваження у сфері процесуальних відносин, пов'язаних із застосуванням заходів забезпечення кримінального провадження в широкому значенні цього поняття (обрання запобіжних заходів); 2) повноваження слідчого судді, пов'язані із розглядом та вирішенням питань щодо дачі дозволу на проведення визначених у законі слідчих (розшукових), негласних слідчих (розшукових) та інших процесуальних дій, спрямованих на збирання сторонами, насамперед стороною обвинувачення, доказів, зокрема, про дозвіл: на обшук житла чи іншого володіння особи, огляд житла чи іншого володіння особи, провадження слідчого експерименту в житлі чи іншому володіння особи, про примусове залучення особи до проведення медичної або психіатричної експертизи, про примусове відбирання зразків для експертного дослідження; 3) повноваження слідчого судді з розгляду та вирішення скарг на рішення, дії чи бездіяльність слідчого або прокурора; 4) повноваження, видами яких є збирання доказів шляхом: допиту у виняткових, передбачених законом, випадках свідка, потерпілого під час досудового 
розслідування в судовому засіданні, в тому числі здійснення такого допиту у режимі відеоконференції, доручення проведення експертизи експертній установі, експерту або експертам; 5) повноваження, пов'язані зі встановленням процесуальних строків: а) за клопотанням заінтересованої особи слідчим суддею поновлюється пропущений із поважних причин строк (ст. 117 КПК); б) для забезпечення виконання сторонами кримінального провадження вимог розумного строку слідчий має право встановлювати процесуальні строки у межах граничного строку, встановленого КПК, з урахуванням обставин, встановлених під час відповідного провадження; в) у разі зволікання для ознайомлення з матеріалами, до яких надано доступ під час відкриття сторонам та потерпілому матеріалів кримінального провадження, слідчий суддя за клопотанням сторони кримінального провадження з урахуванням обсягу, складності та умов доступу зобов'язаний встановити строк для ознайомлення з матеріалами; 6) повноваження із розгляду та вирішення питань про відводи під час досудового розслідування прокурора, слідчого, захисника, представника, спеціаліста, перекладача, експерта, секретаря судового засідання; 7) повноваження щодо вирішення на стадії досудового розслідування долі речових доказів з підстав та за умов, передбачених ч. ч. 6,7 ст. 100 КПК; 8) тільки на підставі його ухвали вирішується питання про використання інформації, отриманої в результаті проведення негласної слідчої (розшукової) дії про ознаки кримінального правопорушення, яке не розслідується у цьому кримінальному провадженні, в іншому кримінальному провадженні (ч. 1 ст. 257 КПК); 9) це низка так званих загальних обов'язків (повноважень) слідчого судді щодо захисту прав людини, закріплених у ст. 206 КПК, реалізація яких полягає у безпосередньому, за власною ініціативою здійсненні ним дій та прийнятті рішень, спрямованих на поновлення свобод незаконно ув'язнених осіб та прав осіб, що перебувають під вартою, на захист інших, передбачених у нормах цієї статті КПК прав та інтересів таких осіб, тобто у судовому контролі за дотриманням прав, свобод та інтересів осіб у кримінальному провадженні. До цієї групи за ознакою подібності за характером слід віднести й повноваження слідчого судді, яке пов'язане з його присутністю під час допиту за запитом компетентного органу іноземної держави за допомогою відео або телефонної конференції, за якого у разі виявлення порушення порядку такого допиту він зупиняє його з метою вжиття заходів для його усунення (ст. 567 КПК) [3, с. 11-16].

Функція судового контролю - це заснована на законі кримінальна процесуальна діяльність спеціально уповноваженого суб'єкта - слідчого судді, що здійснюється шляхом розгляду і вирішення клопотань і скарг сторін кримінального провадження, потерпілого з метою охорони прав і свобод особи та має як превентивний, так і правовідновлювальний характер.

Таким чином, даючи тлумачення поняттю «слідчий суддя», варто пам'ятати, що це - спеціальний суб'єкт судової влади, який здійснює функцію судового контролю за дотриманням прав, свобод та інтересів осіб під час досудового розслідування та організаційно й функціонально належить до суду. Саме процесуальна діяльність слідчого судді є формою захисту прав і свобод учасників кримінального провадження, які будь-який правовий конфлікт, що виникає під час досудового розслідування вирішують шляхом безпосереднього звернення до слідчого 
судді, рішення якого здебільшого є остаточним (за винятком рішень, пов'язаних із застосуванням найбільш суворих запобіжних заходів тримання під вартою, домашній арешт; накладення арешту на майно; відмова в скасуванні постанови про закриття кримінального провадження).

Процесуальна діяльність слідчого судді спрямована на поновлення права фiзичної чи юридичної особи ще до початку кримінального провадження, оскільки заявник, який звернувся із заявою або повідомленням про вчинене кримінальне правопорушення до органу державної влади, уповноваженого розпочати досудове розслідування, але досудове розслідування не було розпочате, вправі оскаржити до слідчого судді таку бездіяльність слідчого, прокурора протягом 10 днів 3 моменту вчинення бездіяльності. Відповідно до ст. 306 КПК України слідчий суддя не пізніше сімдесяти двох годин з моменту надходження відповідної скарги має провести судове засідання за правилами судового розгляду та прийняти рішення про зобов'язання слідчого, прокурора внести відповідні відомості до Єдиного реєстру досудових розслідувань та розпочати досудове розслідування або відмовити в задоволенні скарги.

Судовий контроль - це особливий, самостійний вид судової діяльності, спрямований на забезпечення прав і свобод людини, їх захист і негайне поновлення в разі їх ігнорування слідчим, прокурором. Його особливість визначається спеціальними порядками розгляду клопотань слідчих, прокурорів під час здійснення досудового розслідування та скарг на рішення, дії та бездіяльність слідчого, прокурора, з якими можуть звертатися суб’єкти кримінального провадження та максимально скороченими строками їх розгляду. Кримінальний процесуальний кодекс України визначає конкретні, досить обмежені строки розгляду як клопотань, так і скарг: негайно - розгляд клопотання про дачу дозволу на затримання особи; негайно, але не пізніше 72 годин з моменту фактичного затримання особи або надходження до суду клопотання про застосування запобіжного заходу; у день надходження до суду - обшук; протягом 6 годин з моменту отримання клопотання про проведення негласних слідчих (розшукових) дій; не пізніше 72 годин з моменту надходження скарги на рішення, дію чи бездіяльність слідчого; не пізніше 2 днів з дня надходження до слідчого судді клопотання про арешт майна.

Дієвість інституту слідчого судді суттєво впливає на результативність досудового розслідування та забезпечує застосуванням правових механізмів, визначених кримінальним процесуальним законом, захист особи, суспільства та держави та охорону прав, свобод та законних інтересів учасників кримінального провадження.

\section{Jimepamypa}

1. Кримінальний процесуальний Кодекс України : Закон України в ред. від 5 серпня 2018 року № 4651-V1. URL: http://zakon.rada.gov.ua/laws/show/4651-17.

2. Сучасний кримінальний процес країн Європи : монографія. / В.В. Луцик, В.А. Савченко, B.I. Самарін та ін.; за ред. В.В. Луцика та В.І. Самаріна. Харків : Право, 2018. 792 с.

3. Попелюшко В.О. Слідчий суддя у кримінальному провадженні. Часопис Національного університету «Острозька академія». Серія «Право». 2014. № 1(9).

4. Науково-практичний коментар кримінально-процесуального кодексу України: у 3 т. / за ред. О.В. Стовби. Харків, 2013. Т.1. 528 с. 


\section{Анотація}

Шаренко С. Л., Зуб Л. А. Компаративний аналіз нормативного регулювання діяльності слідчого судді в окремих європейських країнах та в Україні. - Стаття.

Стаття присвячена порівняльно-правовому дослідженню інституту судового контролю на стадії досудового розслідування в різних країнах світу та процесуальній діяльності слідчого судді за кримінальним процесуальним кодексом України. Досліджені повноваження та функції слідчого судді. Обгрунтований висновок про дієвість процесуальної діяльності слідчого судді, спрямованої на охорону прав, свобод та законних інтересів учасників кримінального провадження.

Ключові слова: слідчий суддя, судовий контроль, клопотання слідчого, прокурора, дозвіл на проведення гласних і негласних (розшукових) слідчих дій.

\section{Аннотация}

Шаренко С. Л., Зуб Л. А. Компаративный анализ нормативного регулирования деятельности следственного судьи в отдельных европейских странах и в Украине. - Статья.

Статья посвящена сравнительно-правовому исследованию института судебного контроля на стадии досудебного расследования в различных странах мира и процессуальной деятельности следственного судьи, регламентированной уголовным процессуальным кодексом Украины. Рассмотрены вопросы полномочий следственного судьи, изучены функции следственного судьи. Аргументирован вывод об эффективности процессуальной деятельности следственного судьи по охране прав, свобод и законных интересов участников уголовного производства.

Ключевые слова: следственный судья, судебный контроль, ходатайства следователя, прокурора, разрешение на проведение гласных и негласных (розыскных) следственных действий.

\section{Summary}

Sharenko S. L., Zub L. A. Comparative analysis of regulatory activities of the investigating judge in certain European countries and in Ukraine. - Article.

The article is devoted to a comparative legal study of the institute of judicial control at the stage of pretrial investigation in various countries of the world and the procedural activity of the investigative judge, regulated by the Criminal Procedure Code of Ukraine. The issues of an investigative judge's authorities, which are divided into nine independent groups, are studied here as well as the functions of an investigating judge. The conclusion about the effectiveness of an investigative judge's procedural activities considering the protection of the rights, freedoms and legitimate interests of the participants in criminal proceedings was argued.

Key words: investigative judge, judicial control, petitions of the investigator, prosecutor, permission to conduct public and secret (search) actions. 